\title{
Legalese versus plain
}

language

\author{
by Peter Butt
}

$\mathrm{L}$ egal English has traditionally been a special variety of English. Mysterious in form and expression, it is larded with law-Latin and Norman-French, heavily dependent on the past, and unashamedly archaic. Antiquated words flourish — words such as herein, therein, whereas - words long lost to everyday language. A spurious sense of precision is conjured through liberal use of jargon and stilted formalism: the said, aforesaid, the same, such (used as an adjective). Oddities abound: for example, oath swearers do not believe something, they verily believe it; parties do not wish something, they are desirous of it; the clearest photocopy only purports to be a copy; and so on. All this - and much more - from a profession which regards itself as learned.

In recent years, however, we have seen a growing challenge to traditional legal English. Some in the solicitors' branch of the legal profession have moved to a more relaxed style of writing; some of their precedents and opinions are now drafted in a style that is less formal and self-important. Change at the bar has been less noticeable. Barristers' opinions generally retain the older, more formal style; so do pleadings, except where forced to confront modernity by external pressures such as the Woolf reforms.

I will argue in this article that both branches of the profession should move to a more modern, relaxed style to 'plain legal language' - and that they can do so without loss of legal precision.

We should start with some terminology: what is 'plain language'? Definitions vary, but for me it is language that communicates directly with the audience for which it is written. It allows the reader to understand on a first reading. It is organised in a way that meets the reader's needs, not the writer's needs. It avoids circumlocution and omits surplus words. In short, it uses modern, standard English - English of the kind found every day in the better newspapers and journals.

\section{TRADITIONAL LEGAL DRAFTING}

Why change the way that lawyers have drafted for centuries? Where are the pressures coming from to alter the traditional style of legal writing?
Lest anyone doubt the need to improve the traditional style of legal writing, let me cite several examples. The first is a 'repairing covenant' from a lease that ended up in court on a point of construction (see Ravenseft Properties Ltd v Davstone (Holdings) Ltd [1979] 1 All ER 929):

'[The tenant shall] when where and so often as occasion requires well and sufficiently ... repair renew rebuild uphold support sustain maintain pave purge scour cleanse glaze empty amend and keep the premises and every part thereof ... and all floors walls columns roofs canopies lifts and escalators ... shafts stairways fences pavements forecourts drains sewers ducts flues conduits wires cables gutters soil and other pipes tanks cisterns pumps and other water and sanitary apparatus thereon with all needful and necessary amendments whatsoever ...'.

Lord Hoffmann once described this style of leasedrafting as 'torrential' (see Norwich Union Life Insurance Society v British Railways Board [1987] 2 EGLR 137 at 138). It is a style that exudes verbosity, a verbosity which makes the document far more difficult to read than its subject matter requires. And in the particular case, the verbosity - doubtless prompted by a desire to be precise - did not in the end prevent litigation over meaning. This exposes one of the great misconceptions of traditional legal drafting - that somehow it is more precise than modern, plain language.

Of course, leases are by no means the worst examples we could cite. Mortgages are just as bad. Here is a clause from a current Australian mortgage:

'[The Mortgagor shall pay] Also interest upon all such moneys as aforesaid or on so much thereof as shall for the time being be owing or payable or remain unpaid without (unless the Bank otherwise in writing agrees) allowing credit for any credit balance in any account or accounts of the Mortgagor and the Debtor or either of them either alone or jointly with any other person with the Bank at the rate or respective rates agreed upon in writing if any and in the absence of any such agreement then without prior or other notice to the Mortgagor or to the Debtor at such rate or rates as the Bank from time to time determines: except as otherwise provided by the terms of any agreement in writing relating to the whole or part of such moneys such interest shall accrue from day to day and shall be computed from the day or 
respective days of such moneys being paid or disbursed or becoming owing and at the end of every period of such duration as the Bank may from time to time determine and ending at the end of such day as the Bank may from time to time determine (with power in the Bank to vary from time to time the length of such period or the day or days on which such period ends), or, in the absence of any such effective determination, at the end of each period of one calendar month ending at the end of the last day thereof the interest accrued up to and including such day upon any such moneys in respect of such period or any part thereof shall (if or to the extent to which it has not already been paid) commence and thereafter so long as the whole or any part thereof shall remain unpaid shall continue to carry interest at the rate aforesaid and such accrued but unpaid interest may at the option of the Bank be debited against the Debtor or in the case of interest upon moneys lent paid or advanced to for or on account of the Mortgagor or to for or on account of any other person as aforesaid at the request of the Mortgagor or for the payment of which the Mortgagor is liable to the Bank as hereinbefore stated then against the Mortgagor PROVIDED ALWAYS that such unpaid interest upon which interest shall become so payable shall not be deemed thereby or by reason of any such debiting as aforesaid or by the inclusion of interest with principal in any balance carried forward or account stated or otherwise than as hereinbefore provided to have become capitalised or added to principal but the Bank by express entry to that effect in its books and without the necessity of giving notice to the Debtor or the Mortgagor may at any time and from time to time and as from such date as the Bank shall determine capitalise and add to the principal all or any such unpaid interest upon which interest shall have become so payable and whether such unpaid interest shall have been debited as aforesaid or not and such debitings of interest and additions to principal may be continued and made and the provisions herein contained as to the moneys on which interest is payable shall continue to be applicable so long as any of such moneys remain unpaid notwithstanding that as between the Bank and the Debtor or as between the Bank and the Mortgagor or such other person as aforesaid the relationship of banker and customer may have ceased and notwithstanding the death or bankruptcy of the Mortgagor or of such other person as aforesaid and notwithstanding any composition or compromise entered into or assented to by the Bank with or in respect of the Debtor or the Mortgagor or such other person as aforesaid and notwithstanding any judgment obtained against the Debtor or the Mortgagor or such other person as aforesaid and notwithstanding any other matter or thing whatsoever; in interpreting the foregoing provisions money shall be deemed to remain unpaid notwithstanding any compromise compounding or release made or assented to by the Bank with or in respect of the Debtor or the Mortgagor or such other person as aforesaid until the Bank shall have received the full amount to which it would have been entitled if it had not entered into such compromise compounding or release PROVIDED that the amount of moneys deemed to have remained unpaid shall not include such sums as the Bank shall have received in respect thereof'. [763 words; 2 commas, 1 semi-colon; 3 sets of brackets; no other punctuation]

To some lawyers, drafting feats like these may evoke admiration: after all, who among us can replicate such linguistic leviathans? But for most readers they evoke only bewilderment. Sometimes they bewilder even those who proffer them. In a 1992 Australian case, a bank's standard form of guarantee was so tortuously drafted that the bank manager, when challenged in the witness box, had to admit that he could not understand it; nor, when challenged by the judge, neither could the bank's counsel (Houlahan v Australian and New Zealand Banking Group Ltd (1992) 110 FLR 259). Examples like these aptly illustrate Professor Rodell's aphorism: 'There are two things wrong with almost all legal writing. One is its style. The other is its content. That, I think, about covers the ground'. ('Goodbye to Law Reviews' ((1936) 23 Virginia Law Rev 38.)

And as we know, the style is not peculiar to private legal documents. It pervades statutes as well. Who can forget Lord Justice Harman's cry from the heart, in Davy v Leeds Corporation [1964] 3 All ER 390 at 394, while struggling to glean meaning from the Housing Act 1957:

'To reach a conclusion on this matter involved the court in wading through a monstrous legislative morass, staggering from stone to stone and ignoring the marsh gas exhaling from the forest of schedules lining the way on each side. I regarded it at one time, I must confess, as a Slough of Despond through which the court would never drag its feet, but I have by leaping from tussock to tussock as best I might, eventually, pale and exhausted, reached the other side'.

\section{WHY THE RELUCTANCE TO CHANGE?}

Why do lawyers insist on writing in their turgid, complex, traditional style? Cynics argue that it is to preserve mystique and justify incomes. I doubt that this is the reason. Lawyers rarely draft with this purpose in mind, even subconsciously. Rather, the explanation lies in the ethos in which lawyers find themselves. Three chief factors come to mind: inertia, perceived necessity, and insecurity.

\section{Inertia}

The first factor is inertia. Lawyers uncritically adopt the style that lawyers have always adopted. This style is inculcated in law schools (see Miner, 'Confronting the Communication Crisis in the Legal Profession' (1989) 34 NY Law School Law Rev 1). It is a sad fact, but true, that most law schools in this country make no systematic attempt to teach students the principles of simple, direct writing. Indeed, the reverse is often the case: students are encouraged to adopt a style that is formal and academic. This style might be thought appropriate for law review articles, but it is hardly effective to communicate 
information to non-lawyers - who, after all, are the consumers of much of what lawyers write. That same style is then reinforced in legal practice. It is also mirrored in judicial writing - a circumstance doubly unfortunate, given that judicial writing is a role model for law students. (See further, Stark, 'Why Judges have Nothing to Tell Lawyers about Writing' (1990) 1 Scribes' Journal of Legal Writing 5; Kirby, 'Is Law Poorly Written? A View from the Bench' [1995] New South Wales Law Society Journal (March) 56.)

\section{Necessity}

The second factor is necessity — or, more accurately, perceived necessity. Lawyers write for a potentially hostile audience, in an adversarial atmosphere. Their documents are prone to scrutiny by loophole-seeking opponents. And so lawyers fear (wrongly, in my view) that change may lead to uncertainty, or simplicity to ambiguity. They fear that departing from traditional language and style may lead to defective drafting and the spectre of professional negligence.

\section{Insecurity}

The third factor is insecurity. The pace of modern legal practice reduces the time available to research new ways of expressing old ideas; and when time is short it seems safer to stick with the old than risk the new. Of course, to be completely blunt about it, this insecurity is born partly out of ignorance. Lawyers who are secure in their practice areas know that much of what they write can be recast in plainer language, without fear of a defective product.

\section{THE PITFALLS OF CHANGE}

There are, of course, some dangers in moving to modern, standard English. But most are more imagined than real. On closer examination, most carry no real threat to the validity of legal documents. Let me mention three: complexity, safety, and fear of what judges will think.

\section{Complexity}

It is said, rightly, that some legal concepts are inherently complex. From this it is argued that they are incapable of expression in plain language. Complex concepts require complex language, it is said. However, existing plain language statutes and documents give the lie to this argument.

The 'argument from inherent complexity', as it might be termed, was rebutted convincingly by the Law Reform Commission of Victoria. As part of its 1987 Report on Plain English and the Law, the Commission translated the Victorian Companies (Acquisition of Shares) Code into plain language. The translation was published as an Appendix to the Report. A more complex subject for legislation could hardly be imagined - unless it be income tax legislation (incidentally, the same Commission also studied the comprehensibility of part of the Australian income tax legislation. The result: to understand the legislation (in its form at that time) required 12 years of schooling plus 15 years of university - 27 years of education in all!). Similar plain language 'translations' have since been done in other areas of legislation, both here and in Australia, notably corporations law and taxation. In short, experience to date suggests that no area of law is too complex for plain language. Plain language may not be able to simplify concepts, but it can simplify the way concepts are expressed. Used properly, plain language clarifies complex concepts.

\section{Safety}

Another argument asserts that the traditional style of legal drafting is 'safe', while plain language is not (see the discussion in Kerr, 'Plain Language: Is it Legal?' (1991) New South Wales Law Society Journal 52; also Justice Hwang, 'Plain English in Commercial Contracts' (1990) 32 Malayan Law Review 296). This argument runs that many words and phrases have judicially-defined meanings, and that to substitute a modern word is to lose the benefit of that judicial definition. Meaning may have to be established afresh, perhaps by litigation.

However, this argument appears to have little empirical support. There is no evidence that 'plain language' statutes or documents give rise to more litigation than traditionally-worded documents. If anything, experience with standard-form legal documents suggests the reverse: that a well-drawn plain language document needs no judicial clarification. In contrast, court lists constantly feature cases seeking to divine meaning from traditionallyworded documents.

In any case, the proportion of judicially-defined words and phrases in any given statute or document is likely to be quite small. Research in the United States involving contracts for the sale of land shows that the proportion may be as low as three per cent (Barr, Hathaway, Omichinski and Pratt, 'Legalese and the Myth of Case Precedent' (1985) 64 Michigan Bar Journal 1136).

I do not mean to suggest that converting time-honoured legal phrases into plain language should be undertaken lightly. The translation process can lead to subtle changes in meaning. Further, the plain language version must capture the legal nuances of the original. For this, research may be necessary. To substitute a new phrase for an old, without appreciating the legal significance of the substitution, is as dangerous as using an old phrase without appreciating its significance. Indeed, to know when to substitute the new and when to retain the old when to leave well enough alone - is the most difficult aspect of drafting in plain language. Some genuine legal terms of art are difficult to translate into plain language. Sometimes they embody overtones of meaning that would 
take pages to explain; and sometimes it may even be more efficient to leave them in the document (but preferably adding a note for the reader, explaining their effect).

But none of these concerns, real as they are, justifies using jargon for its own sake. None justifies perpetuating linguistic eccentricities that serve only to enhance mystique, not legal effect. And yet we lawyers still introduce documents with 'whereas'. We 'execute' them rather than sign them. We 'demise' rather than lease. We 'well and sufficiently repair' when 'repair' will do. We declare something 'null and void' - or even 'null and void and of no further force or effect whatsoever' - when 'void' will do. We 'give devise and bequeath' when 'give' will do. We pass 'right, title and interest' when 'interest' will do. Not content with 'convey', we 'hereby convey'. We insist on 'shall' to impose obligation when the rest of the community uses 'must' (for an interesting discussion of 'must' in the Australian Law Journal, see (1989) 63 ALJ 75-78, 522-525, 726-728; (1990) 64 ALJ 168-169. For a more detailed study, see Kimble, 'The many misuses of Shall' (1992) 3 Scribes Journal of Legal Writing, 61-77. In Australia, there is no doubt that 'must' is quite sufficient to impose an obligation: South Australian Housing Trust v Development Assessment Commission (1994) 63 SASR 35 at 38). None of these hallowed words and phrases is a true term of art. All can be simplified, and some can be discarded completely.

\section{Judges and 'tradition'}

It is also sometimes said that judges prefer the 'traditional' style of legal drafting. A statute or document must be drafted to be litigation-proof; and (so the argument runs) since all litigation is decided by judges, and since judges prefer 'traditional' drafting, statutes and documents should be drafted in that way. This argument seems inherently weak; but in any case it is countered by evidence that judges in fact prefer documents to be in plain language. Surveys of American judges show that, given the choice, over 80 per cent would prefer to see pleadings in plain language rather than in traditional form (see Harrington and Kimble, 'Survey: Plain English Wins Every Which Way' (1987) 66 Michigan Bar Journal 1024; Kimble and Prokop, 'Strike Three for Legalese' (1990) 69 Michigan Bar Journal 418; Child, 'Language Preferences of Judges and Lawyers: A Florida Survey' (1990) 64 Florida Bar Journal 32). Judges themselves have occasionally said as much extra-curially: for examples, see Mester, 'Plain English for Judges' (1983) 62 Michigan Bar Journal 978; Cohn, 'Effective Brief Writing: One Judge's Observations' (1983) 62 Michigan Bar Journal 987. As far as I know, no similar surveys have been done of English or Australian judges; but certainly in recent years some English and Australian judges have shown an increased willingness to condemn from the bench legal drafting that is convoluted and unclear. Epithets have included 'botched', 'halfbaked', 'cobbled-together', 'doubtful', 'tortuous', 'archaic', 'incomprehensible legal gobbledegook', and 'singularly inelegant' (these and other examples are discussed in Butt and Castle, Modern Legal Drafting, Cambridge University Press, 2001, chapter 2.)

To be even-handed here, some Australian judges have recently been less than enthusiastic about plain language statutes. For example, Callaway J of the Victorian Court of Appeal scathingly described certain re-drafted provisions of the Corporations Law as reflecting 'the language of the pop songs' (GM \& AM Pearce and Co Pty Ltd v RGM Australia Pty Ltd (1998) 16 ACLC 429 at 432). Another, Meagher JA of the New South Wales Court of Appeal has dismissed plain language as an excuse for split infinitives and woolly thinking. But I suspect that even they would accept - albeit grudgingly - that modern Australian statutes, which are now increasingly being drafted in a plainer style, are far easier to read and apply than their traditionally-drafted forebears.

\section{SOME BENEFITS OF PLAIN LANGUAGE}

Having considered some of the pitfalls, let us now turn to some of the advantages that flow from using modern, standard English - 'plain English' - in statutes and private legal documents. I want to suggest three: efficiency, reduced errors, and the image of the legal profession.

\section{Efficiency}

Plain language statutes and documents are more 'efficient' than traditionally worded ones. They are easier to read, for both lawyers and non-lawyers, saving time for lawyers and non-lawyers. In a study for the Law Reform Commission of Victoria, lawyers read counterpart versions of the same statute, one written in plain language and the other in traditional language. The time taken to understand the plain language version was between onethird to one-half less than the time taken to understand the traditional version (the results are recorded in Eagleson, 'Plain English - A Boon for Lawyers' [1991] The Second Draft, Legal Writing Institute, p. 12.)

Also, because plain language documents are easier to read, queries about meaning are reduced. Many corporations and government agencies here and abroad claim to have saved substantial amounts by converting their standard-form documents to plain language. A recent survey in the United States by Professor Joseph Kimble records numerous examples of impressive savings that have followed the adoption of plain language documents Kimble, 'Writing for Dollars, Writing to Please' (1996-1997) 6 Scribes Journal of Legal Writing 1-38. For another study, see Mills and Duckworth, The Gains from Clarity, Centre for Microeconomic Policy Analysis and Centre for Plain Legal Language, University of Sydney, 1996). 


\section{Disclosing errors}

Secondly, plain language helps expose errors. In contrast, legalese tends to hide inconsistencies and ambiguities, because errors are harder to find in dense, convoluted prose. Examples have been well documented (see Eagleson, 'Efficiency in Legal Drafting', in Essays on Legislative Drafting in Honour of JQ Ewens, St Kelly ed., Adelaide University Press, 1990, pp 25-26). But for an easy illustration, look back at the excessively long lease and mortgage clauses cited near the beginning of this paper; notice how difficult it is to determine whether words or phrases have been dropped out, or legal concepts misphrased. Errors of this kind are more easily discerned when sentences are short and text is broken down into more digestible units.

\section{Image of the legal profession}

Thirdly, plain language enhances the image of the legal profession, the obscurity of whose traditional language has long been a source of ridicule. And quite apart from its obscurity, legal writing is impersonal. It creates barriers of aloofness. It intimidates readers and keeps them in the dark. Surveys in the United States and Canada disclose that readers find legal language 'seriously incomprehensible' and find legal documents 'difficult/very difficult' to read (see Benson, 'The End of Legalese: The Game is Over' (1984-1985) 13 Review of Law \& Social
Change 519, p. 532; Plain Language Institute of British Columbia, Preliminary Report, 'Critical Opinions: The Public's View of Legal Documents' (1992), p 18.) These surveys confirm a widely-held public perception that lawyers are indifferent about communicating clearly.

\section{CONCLUSION}

The benefits of plain legal language greatly outweigh any pitfalls that lie in the path of its adoption. Inevitably, in time, plain language will become the norm. The pressures will be too hard to resist. But it may be a long time coming. Traditional legal language will be a long time dying. But die it will, under the weight of the reality that it is imperfect and that modern, standard English is completely adequate for legal purposes. Wittgenstein once wrote of language, 'Everything that can be put into words can be put clearly'. Legal language is no different. (c)

\section{Peter Butt}

Professor Peter Butt is Associate Professor of Law at the University of Sydney. He is visiting the Institute of Advanced Legal Studies as the Inns of Court Fellow for the first half of 2001. At the University of Sydney he teaches property law, conveyancing, native title and legal drafting. He was a founding director of the Centre for Plain Legal Language at the University of Sydney.

\title{
The Inaugural Sir William Dale Memorial Lecture
}

The Sir William Dale Centre for Legislative Studies at the Institute of Advanced Legal Studies is pleased to announce the following public lecture in memory of Sir William Dale

\section{JUDGE DAME ROSALYN HIGGINS International Court of Justice, The Hague}

\author{
Colonial Law and the Clarity of Drafting: \\ The International Court and \\ William Dale's Two Abiding Interests \\ Monday 2 July 2001, 6pm \\ at the Chancellor's Hall, Senate House, Malet Street, London WC1 \\ Drinks and light refreshments will follow \\ ADMISSION FREE - ALL WELCOME
}

Anyone wishing to attend, or requiring further details, should contact Belinda Crothers at the Institute of Advanced Legal Studies (tel: 0207862 5841; email: bcrother@sas.ac.uk 